$4-1-2001$

\title{
Adenosine Triphosphate-Dependent Degradation of A Fluorescent $\lambda$ N Substrate Mimic by Lon Protease
}

Irene Lee

Case Western Reserve University

Anthony J. Berdis

Cleveland State University, A.BERDIS@csuohio.edu

Follow this and additional works at: https://engagedscholarship.csuohio.edu/scichem_facpub

Part of the Chemistry Commons

How does access to this work benefit you? Let us know!

\section{Recommended Citation}

Lee, Irene and Berdis, Anthony J., "Adenosine Triphosphate-Dependent Degradation of A Fluorescent $\lambda \mathrm{N}$ Substrate Mimic by Lon Protease" (2001). Chemistry Faculty Publications. 169.

https://engagedscholarship.csuohio.edu/scichem_facpub/169

This Article is brought to you for free and open access by the Chemistry Department at EngagedScholarship@CSU. It has been accepted for inclusion in Chemistry Faculty Publications by an authorized administrator of EngagedScholarship@CSU. For more information, please contact library.es@csuohio.edu. 


\title{
Adenosine Triphosphate-Dependent Degradation of a Fluorescent A N Substrate Mimic by Lon Protease
}

\author{
Irene Lee and Anthony J. Berdis
}

Lon is an ATP-dependent protease functioning independently of ubiquitin to degrade abnormal and transient cellular proteins (1-4). Lon eliminates abnormal polypeptides and unstable regulatory proteins in prokaryotes and eukaryotes. In yeast, Lon maintains the integrity of mitochondria and renders respiratory function in cells (5-7) that can be partially complemented

by the Escherichia coli (E. coli) Jon homolog (8). In human, Lon is expressed in the nucleus of all tissues and is localized in mitochondria $(9,10)$. In Brucella abortus, Lon functions as a stress protease that is required for wild-type virulence during the initial stage of infection in mouse (11).

Lon represents a unique class of protease as ATP (3, 12-15) and DNA (16) activate its peptidase activity. However, the molecular mechanism of how these effectors mediate protein degradation is unclear. Several studies have demonstrated that the hydrolysis of small synthetic peptides requires only A TP binding, whereas the degradation of proteins requires additional ATP hydrolysis $(4,12,14,17-20)$. While the nonhydrolyzable ATP analogs ATP ${ }_{-y} S^{2}$ AMPPCP, and AMPPNP support the cleavage of certain tetrapeptide substrates of chymotrypsin as effectively as ATP, these analogs are inferior to ATP in activating casein degradation by Lon (2).

The peptide substrate determinant responsible for peptidase and ATPase stimulation of Lon is also unclear. Until now, only protein but not synthetic peptide substrates stimulate the ATPase activity of Lon. The ability of protein substrates to stimulate ATP hydrolysis was originally attributed to structural features of the protein substrate that are recognition elements for the peptidase site. In this case, AT P hydrolysis is nee- 
essary to unfold protein and to present the scissile peptide bond for Lon-mediated cleavage (2-4). While this hypothesis explains the requirement of ATP hydrolysis in degrading structured proteins such as casein (12) and CcdA (21), it fails to reconcile the observed ATPase stimulation during $\lambda \mathrm{N}$ degradation (20). Since $\lambda N$ does not adopt detectable secondary structure in the absence of RNA $(22,23)$, its degradation should require very little if any ATP-mediated substrate unfolding and presentation.

It has also been proposed that the protein substrateinduced ATPase activity is a regulatory component of the proteolytic activity of L on $(2,3)$. Protein substrates may interact with a putative allosteric site in Lon that is independent of the proteolytic site to promote ADP product release and facilitate ATPase turnover. The location of the allosteric site as well as the recognition determinants on substrate responsible for allosteric site interaction have yet to be determined. However, since $L$ on can also function as a chaperone $(5,24)$, it is plausible that the "putative allosteric site" constitutes part of the chaperone activity of Lon such that interaction of the potential protein substrate with the allosteric site activates the protease activity of Lon.

A detailed mechanistic characterization on the coordination of ATP binding and hydrolysis with peptide hydrolysis by Lon cannot be readily accomplished because of the lack of a suitable peptide substrate that interacts with L on in a manner similar to protein substrate. Since the synthetic peptide substrate Glt-AlaAla-Phe-MNA inhibits ATP hydrolysis by Lon $(2,19)$, it is impossible to utilize this substrate to examine the functional role of the protein-induced ATPase activity of Lon. Although protein substrates stimulate ATP hydrolysis by Lon, they are not convenient peptidase substrates because they contain multiple Lon cleavage sites of varying sequences. Thus, it will be very difficult to directly correlate the binding and hydrolysis of ATP with a specific peptide bond cleavage event. In this study, we used a synthetic peptide mimic of $\lambda \mathrm{N}$ protein to develop a continuous peptidase assay to probe the relationship between substrate/allosteric site interaction with Lon catalysis. We demonstrate that a small synthetic peptide (FRETN 89-98) lacking detectable secondary structure stimulated E. coli Lon ATPase activity. Like its protein counterpart, this peptide was cleaved by $E$. coli Lon at a specific site with high efficiency only in the presence but not in the absence of ATP. The design, synthesis, and the kinetic properties of peptide degradation and Lon ATPase stimulation of this synthetic peptide are presented.

\section{EXPERIMENTAL PROCEDURES}

Materials. Fmoc-protected amino acids, Boc-Abz, and F moc-protected Lys Wang resin were purchased from Advance Chemtech and NovaBiochem. HATU was purchased from PerSeptive Biosystem. All solvents and reagents used for peptide synthesis were purchased from Acros, Aldrich, and Fisher. ATP, AMPPNP, AMPPCP, and ATP $\gamma S$ were purchased from Sigma. Tris buffer, cell culture media, IPTG, and chromotography media were purchased from Fisher and Sigma. Electrospray ionization mass spectrometry (EIMS) of peptide substrate and Lon cleavage products was performed by the Cleveland Mass Spectrometry Facility (Cleveland State University) and amino acid analysis of $\mathrm{E}$. coli Lon was performed by the Kerk Facility (Yale University). E. coli cells overexpressing E. coli Lon were kindly communicated by A. Goldberg (Harvard Medical School) and S. J . Benkovic (Pennsylvania State University). The human Lon overexpression vector was a gift from D. M. Markovitz (U niversity of Michigan Medical Center) and C. Suzuki (New J ersey Medical School).

Peptide synthesis. Solid-phase peptide synthesis was conducted according to the procedure by Garner et al. (25) using an Advanced Chemtech Model 90 tabletop peptide synthesizer. Wang resin preloaded with $\mathrm{F}$ moc amino acid was swollen in DMSO for $12 \mathrm{~h}$ before the synthesis. The Fmoc-protecting group was deprotected with $2 \%$ DBU (v/v) in DMF. F moc-deprotected peptide resins were washed with DMF and NMP in between peptide coupling. Peptide products were cleaved from resin using reagent $\mathrm{K}$ (5\% phenol/5\% water $/ 5 \%$ thioanisole/2.5\% ethanediol/82.5\% TF A) and then precipitated with cold diethyl ether. Crude peptide was purified by reverse-phase HPLC using a semipreparative C18 column (Vydac). The concentrations of pure peptide were initially determined by amino acid analysis from which the extinction coefficient of each peptide was determined by their respective absorbances at $280 \mathrm{~nm}$ according to the Beer-Lambert law. The extinction coefficients were then used to determine peptide concentrations used in this study.

Circular dichroism of FRETN 89-98 and $\lambda$ N 89-98. The CD spectra of $50 \mu \mathrm{M}$ peptide substrates in $10 \mathrm{mM}$ potassium phosphate buffer containing $0.1 \mathrm{mM} \beta$-mercaptoethanol were recorded at $25^{\circ} \mathrm{C}$ using a J asco J -810 spectropolarimeter. CD spectra were the average of eight scans from 190 to $280 \mathrm{~nm}$.

Purification of E. coli Lon. E. coli Lon was purified from an overexpression cell strain using a modified protocol of Goldberg et al. (2). The enzyme was purified in $48 \mathrm{~h}$ to ensure optimal activity of the enzyme. Cell lysate was purified by phosphocellulose P11 and DE 52 cellulose chromatography. Protein fractions containing Lon were analyzed by $12 \%$ SDS-PAGE (26) and fractions of apparent homogeneity were pooled and concentrated by $70 \%$ ammonium sulfate precipitation. Pro- 
tein concentrations were determined by amino acid analysis and Bradford assay (27).

Purification of human Lon protease Cultures of $E$. coli BL21(DE3) hosting the plasmid proEx-1/hLON were induced with $4 \mathrm{mM}$ IPTG for $1 \mathrm{~h}$ at $37^{\circ} \mathrm{C}$. Recombinant $L$ on was purified by phosphocellulose chromatography followed by Ni/NTA resin (28). The resulting protease was quantitated by Bradford assay and analyzed by $10 \%$ SDS-PAGE and Western blot analysis.

ATP-dependent peptidase assay. E. coli Lon (200 $\mathrm{nM}$ ) was incubated with $2 \mu \mathrm{M}$ of peptide substrate with and without $1 \mathrm{mM}$ ATP and $\mathrm{Mg}(\mathrm{OAC})_{2}$ (magnesium acetate) in $25 \mu \mathrm{L}$ of $50 \mathrm{mM}$ Tris- $\mathrm{HCl}, \mathrm{pH} 8.1,100 \mathrm{mM}$ $\beta$-mercaptoethanol, at $37^{\circ} \mathrm{C}$ for $1 \mathrm{~h}$. The reactions were quenched with $1 \mu \mathrm{L}$ of $10 \%$ SDS and then subjected to LC/MS analysis (Cleveland Mass Spectrometer Facility, CSU).

Fluorescent assay of ATP-dependent cleavage of FRETN 89-98. E. coli Lon (125 nM) was incubated with varying concentrations of FRETN 89-98 in $60 \mu \mathrm{L}$ of $50 \mathrm{mM}$ Tris- $\mathrm{HCl}, \mathrm{pH} 8.1$ containing $1 \mathrm{mM}$ ATP, 1 $\mathrm{mM} \mathrm{Mg}(\mathrm{OAC})_{2}$, and $1 \mathrm{mM}$ DTT at $37^{\circ} \mathrm{C}$. Increase in fluor escence due to peptide cleavage was monitored by excitation at $320 \mathrm{~nm}$ and detecting emission at $420 \mathrm{~nm}$ using a Fluorolog 3 fluorometer (Spex Inc.). Background hydrolysis was obtained by incubation of all reaction components except Lon. The amount of peptide hydrolysis was calibrated by determining the amount of fluorescence generated per micromolar peptide due to complete digestion by trypsin under the same reaction conditions. Under our assay conditions, fluorescent signals resulting from complete FRETN 89-98 digestion by trypsin are linear up to $160 \mu \mathrm{M}$ of peptide substrate. Initial rates of FRETN 89-98 cleavage by $E$. coli Lon were calculated from reaction time courses in which less than $5 \%$ of peptide substrate was cleaved. Steady-state kinetic parameters were determined from initial rates of peptide hydrolysis under varying substrate concentrations by fitting data using the computer programs KaleidaGraph (Synergy, Inc.) or Enzfitter (Biosoft, Inc.).

ATPase of E. coli Lon. ATP hydrolysis assays were carried out with $250 \mathrm{nM} \mathrm{E}$. coli Lon, $1 \mathrm{mM} \mathrm{Mg(OAc})_{2}$, $0.5 \mathrm{mM}$ ATP, and $50 \mathrm{nM}\left[\gamma^{32} \mathrm{P}\right] \mathrm{ATP}$ at $37^{\circ} \mathrm{C}$. The ATPase activity of $\mathrm{E}$. coli Lon was also measured in the presence of $20 \mu \mathrm{M}$ casein or $100 \mu \mathrm{M}$ peptide substrates under the same conditions. Time courses for each re action were obtained by quenching and analyzing reaction aliquots as using thin-layer chromatography followed by Phosphorl maging as described by Berdis and Benkovic (29).

\section{RESULTS}

Peptide design and synthesis. The Fmoc solidphase peptide synthesis technique (30) was used to
A FRETN 89-98

076

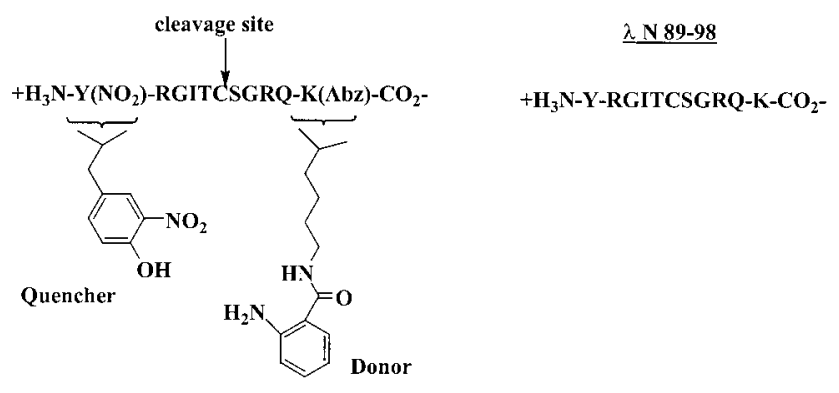

B Glt-Ala-Ala-Phe-MNA cleavage site

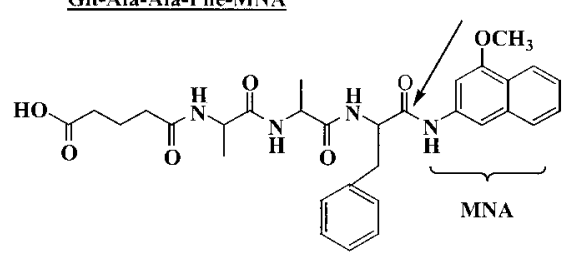

FIG. 1. Peptide substrates of E. coli Lon protease. (A) The 10amino-acid synthetic peptide FRETN 89-98 is designed as an in vitro substrate mimic of the $\lambda \mathrm{N}$ protein. This substrate consists of residues 89-98 of $\lambda \mathrm{N}$, a fluorophore anthranilamide (Abz) lysine and a fluorescence quencher 3-nitrotyrosine. The $\mathrm{E}$. coli Lon cleavage site is located at Cys93 and Ser94. The FRETN 89-98 cleavage reaction by $\mathrm{E}$. coli Lon is monitored by increase in fluorescence caused by separation of Abz from 3-nitrotyrosine. (B) The Lon cleavage site of GIt-Ala-Ala-Phe-MNA is located at the carboxyl end of the tetrapeptide. Peptidase activity is monitored by an increase in fluorescence due to release of 2-methoxynaphthylamine (MNA).

generate a 10-amino-acid peptide FRETN 89-98 containing a fluorescent donor and a quencher (Fig. 1A). The sequence of FRETN 89-98 corresponds to residues 89-98 of $\lambda \mathrm{N}$ protein with a Lon cleavage site at Cys98 and Ser94 (20). Consequently the sulfhydryl moiety of this substrate can be derivatized by a variety of spectroscopic probes or crosslinkers to probe the peptide and Lon interaction. The peptide sequence of FRETN 89-98 is chosen because it contains a unique Cys at the Lon cleavage site. FRETN 89-98 differs from other $L$ on peptide substrates such as Glt-Ala-Ala-Phe-MNA (19) by its slightly larger size and by the location of the Lon cleavage site in the middle of the peptide sequence (Fig. 1A). FRETN 89-98 also differs from the $\lambda$ N protein by a shorter chain length and the lack of multiple Lon cleavage sites. Due to internal quenching of anthranilaminde (Abz) Iysine by 3-nitrotyrosine (31, 32), FRETN 89-98 is minimally fluorescent until cleavage by Lon that separates the donor from the quencher. Consequently, the peptidase activity of Lon can be continuously monitored by fluorometry at excitation wavelength $320 \mathrm{~nm}$ and emission wavelength $420 \mathrm{~nm}$. Furthermore, the increase in substrate size in relationship to the tetrapeptide in use (GIt-Ala-Ala-Phe-MNA) is designed to concomitantly probe the correlation of 
peptide length with ATPase stimulation and efficiency of hydrolysis. Comparison of the ATPase stimulation by FRETN 89-98 with other unstructured substrates of varying length, such as $\lambda \mathrm{N}$ protein and Glt-Ala-AlaPhe-MNA, allows for direct comparison on the efficacy of FRETN 89-98 as a substrate. Characterization of FRETN 89-98 degradation by $E$. col i Lon can befurther compared directly with the degradation of $\lambda \mathrm{N}$ to assess the efficacy of FRETN 89-98 as a peptidase substrate as well as an ATPase stimulator.

FRETN 89-98 was synthesized using the protocol of Garner et al. (25) in which the quencher 3-nitrotyrosine and the fluorophore BocAbz were introduced into FRETN 89-98 via HATU coupling (30). Target peptide of at least 95\% pure was readily purified by C18 reverse-phase HPLC using a linear gradient of $0.05 \% \mathrm{TFA} / \mathrm{H}_{2} \mathrm{O}$ and $0.05 \% \mathrm{ACN} / \mathrm{H}_{2} \mathrm{O}$. The molecular weight of FRETN 89-98 was 1432 as determined by ESIMS analysis (33) and agreed well with the predicted molecular weight of 1432.57. The nonfluorogenic peptide $\lambda \mathrm{N}$ 89-98 (Fig. 1A) which differs from FRETN 89-98 by replacement of the 3-( $\left.\mathrm{NO}_{2}\right) \mathrm{Tyr}$ (fluorescence quencher) with Tyr and Abz-Lys (fluorophore) with Lys was also synthesized and used as a control to assess the contribution of ATPase stimulation caused by the quencher and the fluorophore. The respective absorption extinction coefficients for FRETN 89-98 and $\lambda \mathrm{N}$ 89-98 at $280 \mathrm{~nm}$ were 5650 and $1321 \mathrm{M}^{-1} \mathrm{~cm}^{-1}$ as determined by amino acid analysis along with spectrophotometer using the Beer-Lambert law (27). Circular dichroism analysis (Fig. 2) of FRETN 89-98 and $\lambda \mathrm{N}$ 89-98 indicated that both synthetic peptides did not adopt defined secondary structure (34), consistent with the reported lack of secondary structure of $\lambda \mathrm{N}$ protein (23).

Nucleotide-dependent degradation of FRETN 89-98 by $E$. coli Lon. Prior to spectroscopic analysis of FRETN 89-98 degradation, we determined the cleavage specificity of FRETN 89-98 by $E$. coli Lon in the presence of $1 \mathrm{mM}$ ATP using LC/ESIMS analysis (Fig. 3). Reaction mixtures containing $E$. coli Lon and FRETN 89-98 in the presence and absence of ATP were resolved by reverse-phase HPLC from which the molecular mass of each peak was determined by ESIMS (Table 1). As seen in Fig. 3, FRETN 89-98 was specifically cleaved by E. coli Lon at Cys93 and Ser94 in the presence of ATP. An internal reference, $\mathrm{Y}\left(\mathrm{NO}_{2}\right) \mathrm{RGITC}$, was included to demonstrate that this peptide remained intact during FRETN 89-98 degradation, thereby demonstrating the specificity of FRETN 89-98. Based upon the aforementioned data, we conclude that the ATP-dependent cleavage of F RETN 89-98 by E. coli Lon was highly specific since cleavage was only observed between Cys93 and Ser94 and was dependent upon the presence of ATP.

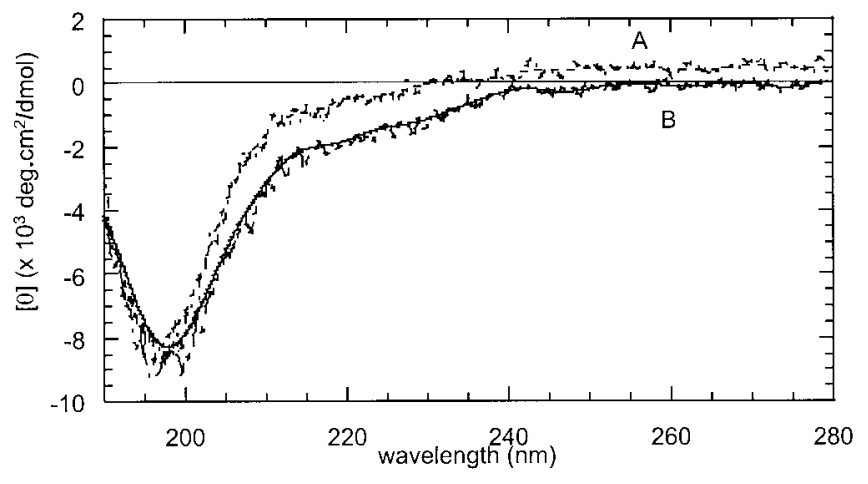

FIG. 2. Circular dichroism of FRETN 89-98 and $\lambda \mathrm{N}$ 89-98. The spectra of $50 \mu \mathrm{M}$ of peptide samples were recorded in $10 \mathrm{mM}$ potassium phosphate, $\mathrm{pH} 7$, with $0.1 \mathrm{mM} \beta$-mercaptoethanol at $25^{\circ} \mathrm{C}$ as described under Experimental Procedures. Both $\lambda \mathrm{N}$ 89-98 (A) and FRETN 89-98 (B) display random coil structure as judged by the lack of $\alpha$ helix (two negative absorptions near 222 and $208 \mathrm{~nm}$ ) and $\beta$ (a negative absorption near $217 \mathrm{~nm}$ ) signals in the spectra. Analysis of the two spectra by the J asco secondary structure estimation software ( asco) also indicates random structures in both peptides. The raw data were overlaid with the noise-reduced data (smooth lines) processed by the noise-reduction program supplied by J asco. The molar ellipticity values on the $y$ axis are calculated from the raw data using the equation $[\theta]=[\theta]_{\text {obs }}(\mathrm{mrw}) / 10$ Ic (Ref. 25$)$, where $[\theta]_{\mathrm{obs}}$ is the measured ellipticity in degrees, $\mathrm{mrw}$ is the molecular weight of the peptide divided by the number of amino acid residues, $c$ is the peptide concentration in grams/milliliter, and I is the optical pathlength of the cell in centimeters.

The presence of the FRET pair 3-nitrotyrosine and Abz-Iysine allowed for the cleavage of FRETN 89-98 to be monitored by fluorescence spectroscopy. The usable range of FRETN 89-98 as a peptidase substrate was assessed by determining the change in fluorescence resulting from varying concentrations of FRETN 89-98 cleavage by trypsin. A linear increase in fluorescence change is observed for up to $160 \mu \mathrm{M}$ of FRETN 89-98 degradation (Fig. 4). At high peptide concentrations, the increase in fluorescence due to F RETN 89-98 cleavage is reduced due to inner filter effect (35) resulting from high concentration of nitrotyrosine present in the reactions. This inner filter effect is corrected for by determining the percentage of reduction in fluorescence at the indicated peptide concentrations. The corrected rate of peptide cleavage is obtained by dividing the observed fluorescence by the percentage of fluorescence reduction at the corresponding substrate concentration. Trypsin cleaves peptide substrate containing basic residues. Since FRETN 89-98 contains two arginine residues that are cleavage sites of trypsin, the fluorescent signals resulting from compl ete separation of the quencher and acceptor at a specific F RETN 89-98 concentration can be deduced by digesting the peptide with trypsin. Extensive digestion of FRETN 89-98 with $\mathrm{E}$. coli $\mathrm{L}$ on for $1 \mathrm{~h}$ at $37^{\circ} \mathrm{C}$ also generates the same end point result as trypsin (data not 

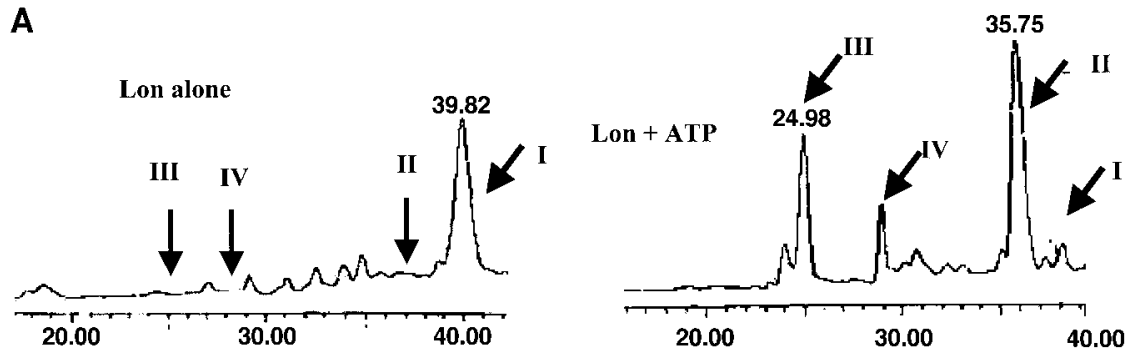

B
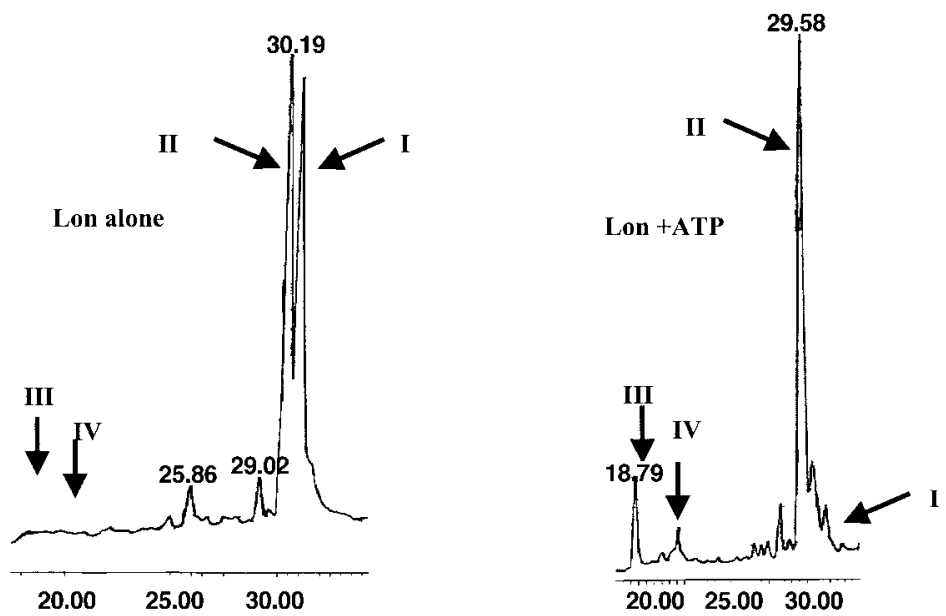

FIG. 3. Site-specific cleavage of FRETN $89-98$ by E. coli Lon. (A) $2 \mu \mathrm{M}$ NFRET $89-98$ (peak I) was incubated with $200 \mathrm{nM}$ E. coli Lon in $25 \mu \mathrm{L}$ of $50 \mathrm{mM}$ Tris- $\mathrm{HCl}, \mathrm{pH} 8.1,100 \mathrm{mM} \beta$-mercaptoethanol in the presence and absence of $1 \mathrm{mM} \mathrm{Mg}(\mathrm{OAC})_{2}$ and ATP at $37^{\circ} \mathrm{C}$ for $1 \mathrm{~h}$, quenched with $1 \mu \mathrm{l}$ of $10 \% \mathrm{SDS}$, and then stored at $-20^{\circ} \mathrm{C}$ until LC/ESIMS analysis. The molecular ion of the intact peptide detected was 1507.44 (peak I) while the molecular ions of the cleavage products were 833.69 (peak II) and 693.28 (peak III), respectively. Both peaks I and III were 76 mass units higher than the expected peptide fragment product (Table 1), suggesting that FRETN 89-98 was chemically modified during the analysis. (B) An internal peptide reference containing residues 3-nitrotyrosine and residues 89-93 of NFRET 89-98 (peak II) was included in the reaction. The presence of ATP leads to complete digestion of NFRET 89-98 as indicated by the absence of peak I in the right panel. The presence of peak II in both reactions indicated that E. coli Lon only cleaves NFRET 89-98 between Cys93 and Ser94 to generate peaks II and III. In the presence of $100 \mathrm{mM} \beta$-mercaptoethanol, the molecular ions of peaks I, II, and III were 1433.3, 757.7, and 693.35, respectively. Compared to A, the lack of peptide modification in the presence of highly reducing conditions (100 mM $\beta$-mercaptoethanol) indicates that the sulfhydryl moiety at Cys93 of FRETN 89-98 is susceptible to oxidation.

shown). Since complete digestion of FRETN 89-98 is readily accomplished within 1 min using trypsin, we chose to use trypsin degradation for routine calibration determination.

TABLE 1

LC/ESIMS Analysis of FRETN 89-98 Degradation by $\mathrm{E}$. coli Lon

\begin{tabular}{lcl}
\hline & Molecular ion & \\
Peak & $(\mathrm{M}+\mathrm{H}) / \mathrm{z}, \mathrm{z}=1$ & \multicolumn{1}{c}{ Corresponding peptide sequence } \\
\hline I & 1432.1 & ${ }^{+} \mathrm{H}_{3} \mathrm{~N}-\mathrm{Y}\left(\mathrm{NO}_{2}\right) \mathrm{RGITCSGRQK}(\mathrm{Abz})-\mathrm{CO}_{2}^{-}$ \\
II & 757.266 & ${ }^{+} \mathrm{H}_{3} \mathrm{~N}-\mathrm{Y}\left(\mathrm{NO}_{2}\right) \mathrm{RGITC}-\mathrm{CO}_{2}^{-}$ \\
III & 694.289 & ${ }^{+} \mathrm{H}_{3} \mathrm{~N}-\mathrm{SGRQK}(\mathrm{Abz})-\mathrm{CO}_{2}^{-}$ \\
IV & 644.912 & Unidentified \\
\hline
\end{tabular}

Note FRETN 89-98 $(2 \mu \mathrm{M})$ was digested by $200 \mathrm{nM}$ E. coli Lon in the presence of $1 \mathrm{mM}$ ATP. Reaction mixture was quenched by $0.5 \%$ SDS (final concentration) and then analysis by liquid chromatography/electrospray ionization mass spectrometry (LC/ESIMS). The LC-resolved molecular ions of the Lon cleavage products and intact FRETN 89-98 were determined by electrospray ionization mass spectrometry.

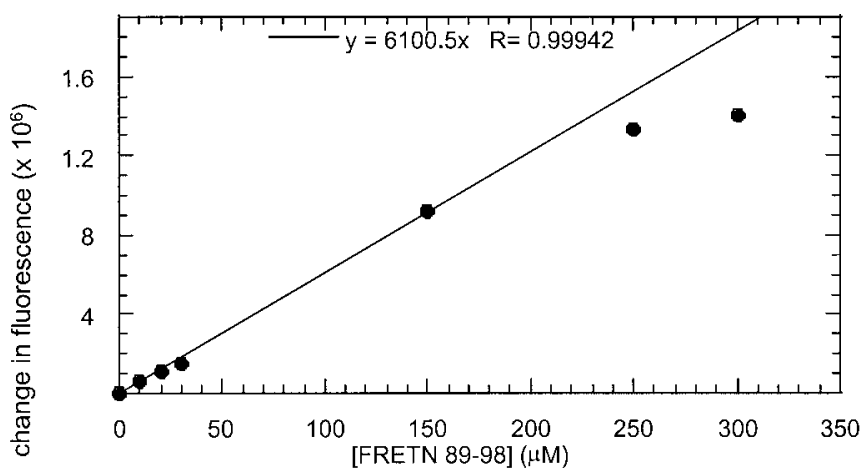

FIG. 4. Calibration curve of FRETN 89-98 digestion by trypsin. Each concentration of FRETN 89-98 was digested with $1.2 \mu \mathrm{M}$ trypsin at $37^{\circ} \mathrm{C}$ until no increase in fluorescence at $420 \mathrm{~nm}$ was detected. The net changes in fluorescence due to complete trypsin digestion are plotted against the respective substrate concentrations to establish a linear calibration curve for FRETN 89-98 degradation by E. coli Lon. The inner filter effects at the nonlinear range of the fluorescence intensities at 250 and $300 \mu \mathrm{M}$ peptide are corrected by determining the percentage decrease in fluorescence intensities at the respective peptide concentrations. 


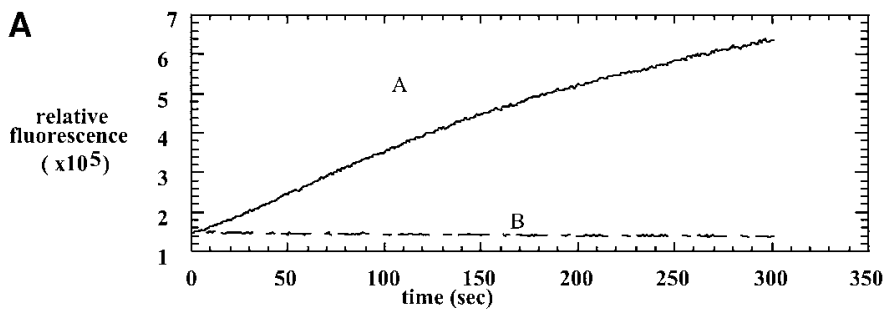

B

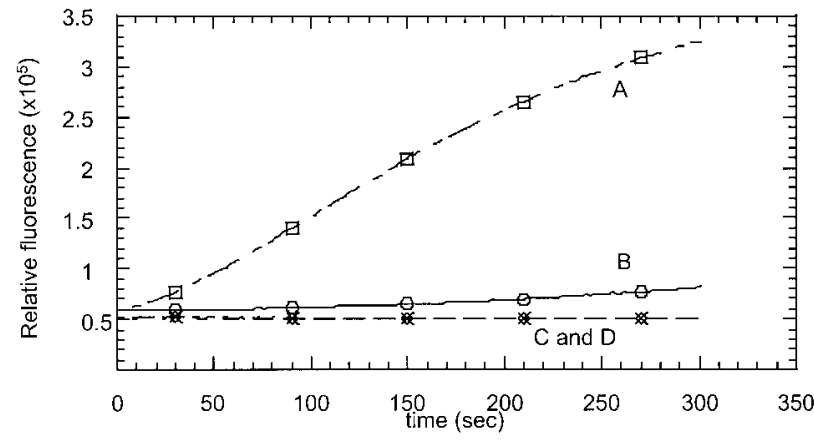

FIG. 5. (A) Spectrofluorometric detection of NFRET 89-98 cleavage by E. coli Lon. FRETN 89-98 $(60 \mu \mathrm{M})$ was incubated with $250 \mathrm{nM}$ of E. coli Lon in the presence (A) and absence (B) of $1 \mathrm{mM}$ ATP as described under Experimental Procedures. Undigested FRETN 89-98 possess intrinsic fluorescence due to incomplete internal quenching of $\mathrm{Abz}$ by $\left(\mathrm{NO}_{2}\right) \mathrm{Tyr}$. Fluorescence changes (excitation at $320 \mathrm{~nm}$ and emission at $420 \mathrm{~nm}$ ) are only detected in the reaction with Lon and ATP. The ATP-dependent fluorescence time course is nonlinear. The initial rate of peptide hydrolysis is calculated from the first phase of the reaction. (B) Nucleotide-dependent cleavage of FRETN 89-98 by E. coli Lon. FRETN 89-98 $(86 \mu \mathrm{M})$ was digested with $125 \mathrm{nM} \mathrm{E}$. coli Lon at $37^{\circ} \mathrm{C}$ in the presence of ATP or nonhydrolyzable ATP analogs. Comparing the time courses of fluorescence change due to FRETN 89-98 digestion by $\mathrm{E}$. coli Lon in the presence of (A) $0.5 \mathrm{mM}$ ATP, (B) $0.5 \mathrm{mM}$ AMPPNP, (C) ATP $\gamma \mathrm{S}$, and (D) AMPPCP indicates that peptide degradation is only supported by ATP and AMPPNP and ATP is eight times more efficient than AMPPNP in mediating FRETN 89-98 cleavage.

Figure 5A shows the time course of $60 \mu \mathrm{M}$ FRETN 89-98 degradation by $250 \mathrm{nM}$ E. coli Lon in which an increase in fluorescence over time was observed only in the presence but not the absence of $1 \mathrm{mM}$ ATP. The time course of FRETN 89-98 degradation exhibited nonlinear behavior. The first phase corresponds to the initial rate of peptide hydrolysis, whereas the second phase might be attributed to inhibition of peptidase activity caused by the accumulation of ADP product (see ATPase assay below) as well as peptide substrate depletion. Using the FRET peptidase assay, we were able to further demonstrate that ATP was the pre ferred nucleotide in FRETN 89-98 cleavage by E. coli Lon (Fig. 5B). Comparing the relative fluorescence intensities as a function of time in the presence of $0.5 \mathrm{mM}$ ATP or $0.5 \mathrm{mM}$ nonhydrolyzable ATP analogs indicated that only ATP and AMPPNP support FRETN 89-98 degradation. Furthermore, ATP is eight times more effective than AMPPNP in mediating FRETN 89-98 cleavage. This result is consistent with the re ported observation that AMPPNP is less efficient than ATP in supporting $\lambda N$ protein degradation (20).

Kinetic characterization of FRETN 89-98 degradation. The degradation of FRETN 89-98 by E. coli Lon in the presence of $0.5 \mathrm{mM}$ ATP exhibited sigmodial kinetics (Fig. 6). The kinetic parameter $[S]_{0.5}$ corresponds to the concentration of peptide substrate required to achieve $50 \% \mathrm{~V}_{\max }$ and is used as a $\mathrm{K}_{\mathrm{m}}$ equivalent for comparison with other Lon substrates. Although FRETN 89-98 is a synthetic peptide containing only one L on cleavage site, it exhibits a specificity constant $\left(\mathrm{k}_{\text {cat }} /[\mathrm{S}]_{0.5}\right)$ comparable to those of the protein substrates (Table 2). The data presented in Fig. 6A were performed in triplicate from which the average values were fitted to the Hill equation (36) $\mathrm{v}=$ $\mathrm{V}_{\max }[\mathrm{S}]^{\mathrm{n}} / \mathrm{K}^{\prime}+[\mathrm{S}]^{\mathrm{n}}$, where $\mathrm{v}$ is the observed rate of

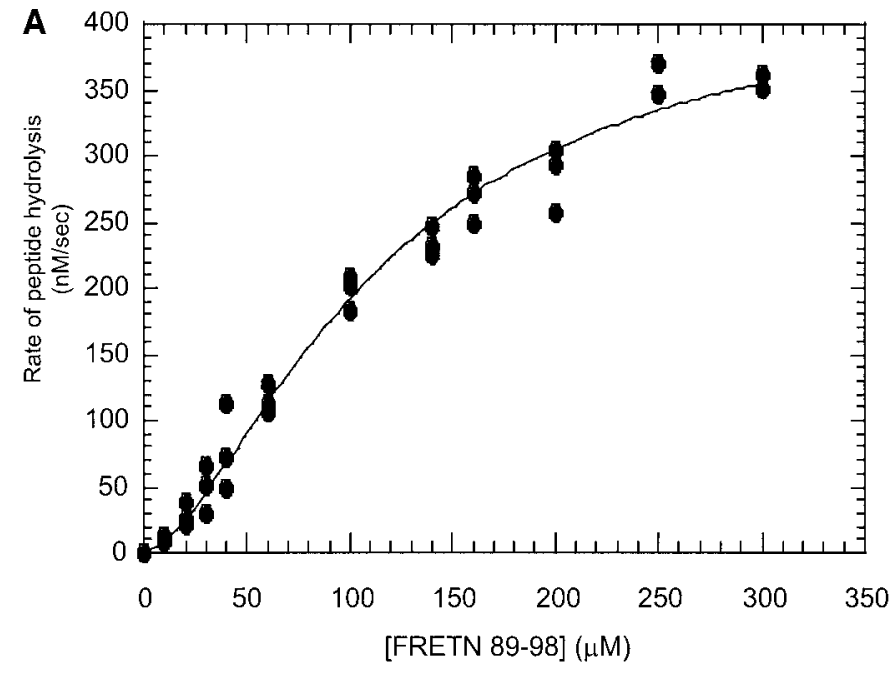

B

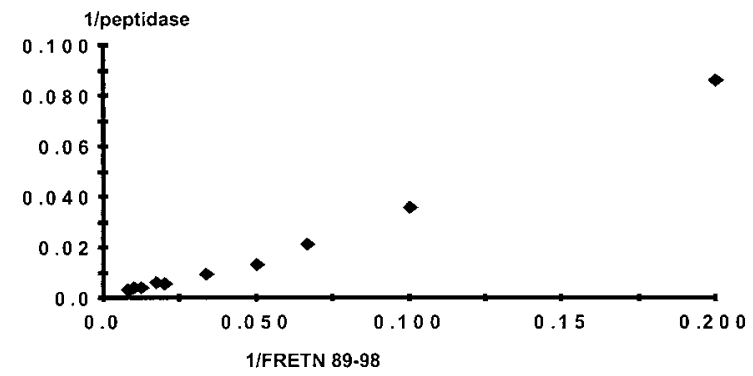

FIG. 6. (A) Steady-state kinetics of FRETN 89-98 degradation by E. coli Lon. E. coli Lon (125 nM) was incubated with varying concentrations of FRETN 89-98. The initial rates of peptide hydrolysis were deduced by dividing the rate of fluorescence changes by the change in fluorescence per $\mu$ M FRETN 89-98 degradation (see Fig. 4). The velocity curve of FRETN 89-98 degradation exhibits sigmodial kinetics, indicating that the rate of peptide cleavage is faster at high substrate concentrations. (B) Double reciprocal plot of FRETN 89-98 degradation by E. coli Lon. The data presented in A are averaged to generate the double reciprocal plot. The observed concave plot is consistent with sigmodial enzyme kinetics in FRETN 89-98 degradation. 


\section{TABLE 2}

Steady-State Kinetic Parameters of $\mathrm{E}$. col $\mathrm{i}$ Lon Substrate Degradation

\begin{tabular}{lccc}
\hline \multicolumn{1}{c}{ Substrate } & $\mathrm{k}_{\text {cat }}\left(\mathrm{s}^{-1}\right)$ & $\mathrm{K}_{\mathrm{m}}(\mu \mathrm{M})$ & $\begin{array}{c}\mathrm{K}_{\text {cat }} / \mathrm{K}_{\mathrm{m}} \\
\left(\times 10^{4} \mathrm{M}^{-1} \mathrm{~s}^{-1}\right)\end{array}$ \\
\hline N protein $^{\mathrm{a}}$ & 1 & 13 & 7.7 \\
FRETN 89-98 $^{\mathrm{b}}$ & $3.2 \pm 0.3$ & $106 \pm 21$ & $3^{\mathrm{d}}$ \\
Casein $^{\mathrm{a}}$ & 0.03 & 2.5 & 1.3 \\
Glt-Ala-Ala-Phe-MNA $^{\mathrm{c}}$ & 0.011 & $400-500$ & 0.0027 \\
\hline
\end{tabular}

\footnotetext{
a The kinetic constants were obtained from Ref. (20).

${ }^{b}$ The kinetic constants were reported as average values of three independent assays.

' The kinetic constants were obtained from Ref. (19).

${ }^{d} k_{\text {cat }} /[S]_{0.5}$ for FRETN 89-98 degradation.
}

peptide hydrolysis, [S] is the peptide concentration, $n$ is the Hill coefficient, and $\mathrm{K}^{\prime}$ is a constant comprising the allosteric enzyme subunit interaction factors and the intrinsic substrate dissociation constant. When $\mathrm{v}=$ $0.5 \mathrm{~V}_{\max }, \mathrm{nlog}[\mathrm{S}]_{0.5}=\log \mathrm{K}^{\prime}$. According to the data shown in $\mathrm{Fig}$. $6 \mathrm{~A}$, the Hill constant is 1.6, the apparent $\mathrm{K}_{\mathrm{m}}$ or $[\mathrm{S}]_{0.5}$ is $106 \pm 21 \mu \mathrm{M}$, and the $\mathrm{k}_{\text {cat }}$ is $3.2 \pm 0.3 \mathrm{~s}^{-1}$. Although the apparent [S $]_{0.5}$ of FRETN $89-98$ is 10 times higher than that of $\lambda \mathrm{N}$, it is at least 4-5 times lower than that of GIt-Ala-Ala-Phe-MNA (Table 2). The double reciprocal of FRETN 89-98 degradation is shown in Fig. 6B. The concave plot is diagnostic of sigmoidal enzyme kinetics.

Stimulation of E. coli Lon ATPase by FRETN 89-98. The ability of FRETN 89-98 to stimulate ATP hydroIysis by $E$. coli Lon was assessed using a radioactive assay that detected ${ }^{32} \mathrm{P}_{\mathrm{i}}$ resulting from $\left[\gamma^{32} \mathrm{P}\right] \mathrm{ATP}$ hydrolysis. The hydrolyzed ATP products were separated by TLC from which the production of ${ }^{32} \mathrm{P}_{\mathrm{i}}$ over time was quantitated by Phosphorlmaging. Figure 7 shows the time courses of ATP hydrolysis by $E$. coli Lon al one and in the presence of $20 \mu \mathrm{M}$ casein, $100 \mu \mathrm{M}$ F RETN 89-98, or $100 \mu \mathrm{M} \lambda \mathrm{N}$ 89-98. E. coli Lon exhibited intrinsic ATPase activity that was stimulated by either peptide or protein substrates. All the time courses shown in Fig. 7 are nonlinear, presumably caused by accumulation of ADP product inhibiting ATP hydrolysis as well as by depletion of peptide or casein substrate (in time courses B, C, and D). I nclusion of an ADP-regenerating enzyme system ( $3 \mathrm{mM}$ phosphoenolpyruvate and 3 units/ml of pyruvate kinase) alleviated the ADP inhibition process and extended the linear range of ATP hydrolysis (data not shown). According to Fig. 7, both FRETN 89-98 and $\lambda$ N 89-98 exhibit the same ATPase stimulation under identical reaction conditions. This result excludes the possibility that the FRET moieties stimulate Lon ATPase. In the presence of $100 \mu \mathrm{M}$ peptide substrates, the ATPase activity of E. coli Lon was elevated by 2.5-fold. Casein, on the other hand, stimulated ATP hydrolysis of Lon by 4.5 -fold at $20 \mu \mathrm{M}$. The latter observation is consistent with published data (19) and thus serves as a positive control in our experiment. Comparison of the time courses in Fig. 7 also shows that casein differs from peptide substrates by its relative resistance to ADP inhibition. This result is consistent with previous report on protein substrates stimulate ATP hydrolysis by promoting ADP release $(12,13)$. In this case, more ATP is hydrolyzed by $\mathrm{E}$. col i Lon in the presence of casein because the protein substrate is more effective in promoting ADP release.

ATP-dependent degradation of FRETN 89-98 by human Lon. The FRETN 89-98 peptide is also a substrate of the truncated recombinant human Lon (10, 28). This recombinant enzyme has been demonstrated to bind to mitochondrial DNA at specific sites (28) and exhibit ATP-dependent casein degradation activity (10). As shown in Fig. 8A, FRETN 89-98 is also degraded by $83 \mathrm{nM}$ human Lon in the presence but not in the absence of $0.5 \mathrm{mM}$ ATP. Under this reaction condition, the rate of FRETN 89-98 cleavage is $2 \mathrm{nM} / \mathrm{s}$. Direct comparison of the rates of FRETN 89-98 cleav-

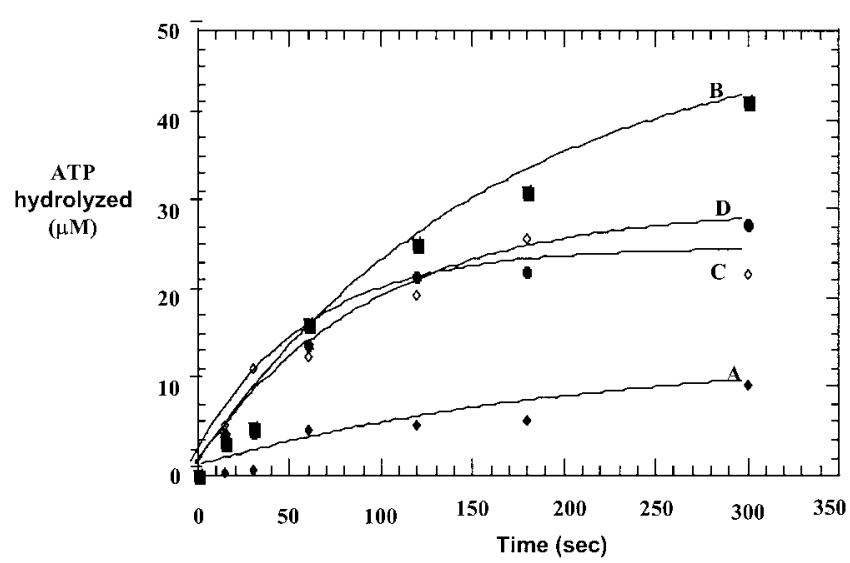

FIG. 7. Stimulation of E. coli Lon ATPase by casein and peptide substrates. ATP hydrolysis assays were carried out with $250 \mathrm{nM} E$. coli Lon, $1 \mathrm{mM} \mathrm{Mg(OAC})_{2}, 0.5 \mathrm{mM}$ ATP, and $50 \mathrm{nM}\left[\gamma_{-}{ }^{32} \mathrm{P}\right] \mathrm{ATP}$ at $37^{\circ} \mathrm{C}(\mathrm{A})$. The effects of casein (B), FRETN 89-98 (C), and $\lambda \mathrm{N}$ 89-98 (D) on E. coli Lon ATPase activity were assessed by monitoring the ATPase time courses of E. coli Lon in the presence of each protein or peptide substrates. Reaction aliquots were quenched at the indicated times from which the hydrolyzed products were analyzed by thinlayer chromatography. The time courses of ATP hydrolysis were quantitated by the increase in ${ }^{32} \mathrm{P}$ liberation over time. All four ATPase reactions display complex time courses. The initial phases of the time courses are linear. The slow phases of the time course are partially contributed by ADP product inhibition since removal of ADP by inclusion of phosphoenol pyruvate kinase and phosphoenolpyruvate in the reaction extends the linearity of the first phases of the reactions (data not shown). In time courses B, C, and D, the nonlinear time courses are also contributed by peptide or protein substrate depletion as the reaction progress. The initial rates of ATPase stimulation by casein, FRETN 89-98, and $\lambda$ N 89-98 are identical. Compared to the casein and peptide induced ATPase activity, the intrinsic E. coli Lon ATPase activity is two- to fourfold lower after $300 \mathrm{~s}$ of reaction. 

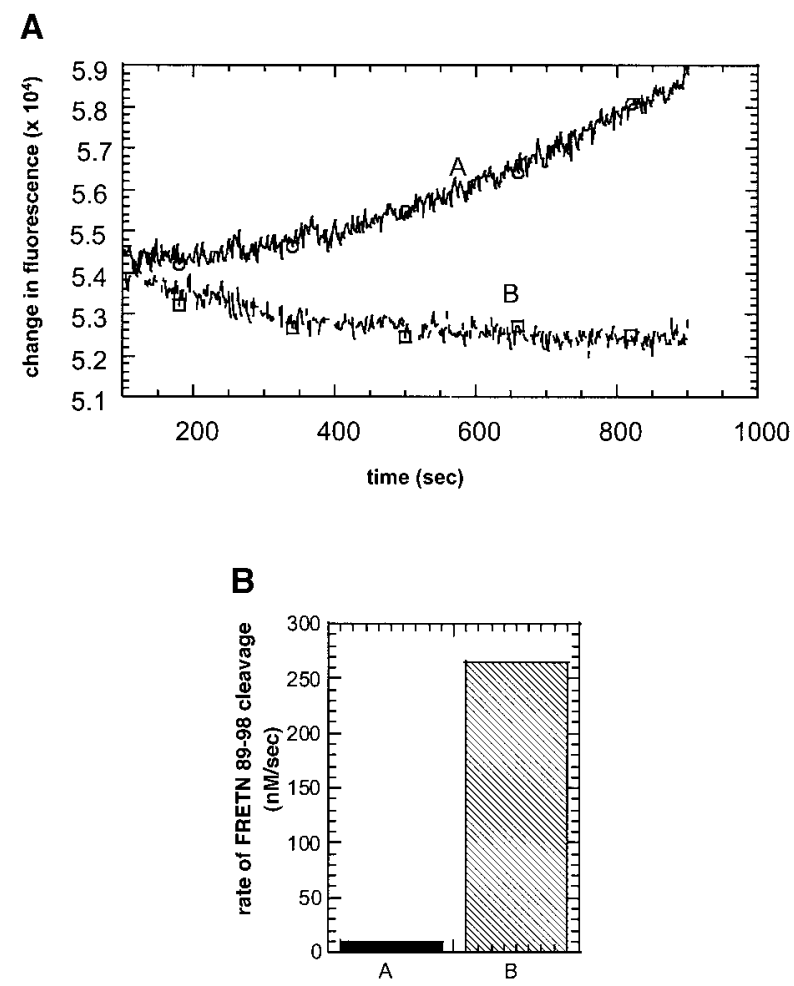

FIG. 8. (A) ATP-dependent degradation of FRETN 89-98 by recombinant human Lon. FRETN 89-98 (86 $\mu \mathrm{M})$ was digested with $83 \mathrm{nM}$ recombinant human $\mathrm{L}$ on at $37^{\circ} \mathrm{C}$ using the reaction conditions for $\mathrm{E}$. coli Lon. An increase in fluorescence is detected only in the presence of $0.5 \mathrm{mM}$ ATP, indicating that the degradation of FRETN 89-98 by human Lon exhibits ATP-dependency. (B) Comparison of the rate of FRETN 89-98 cleavage by $E$. coli and truncated human Lon. FRETN 89-98 $(160 \mu \mathrm{M})$ was digested with $125 \mathrm{nM}$ human Lon (A) or $125 \mathrm{nM}$ $\mathrm{E}$. coli $\mathrm{L}$ on $(\mathrm{B})$ in the presence of $0.5 \mathrm{mM}$ ATP at $\mathrm{pH} 8.1$ at $37^{\circ} \mathrm{C}$. The data presented in A are an average of two assays with less than $10 \%$ experimental variation. The data presented in B are an average of three assays with less than $16 \%$ experimental variation. The rate of FRETN 89-98 cleavage was monitored as described under Experimental Procedures using E. coli Lon enzyme. The rate of FRETN 89-98 deavage by human Lon is 25 -fold slower than that by $\mathrm{E}$. coli Lon.

age by the human and $\mathrm{E}$. coli Ion homologs indicates that FRETN 89-98 is a better substrate for the bacterial enzyme because under identical reaction conditions the rate of FRETN 89-98 cleavage is $11 \pm 0.7$ $\mathrm{nM} / \mathrm{s}$ by human Lon and $265.3 \pm 19.2 \mathrm{nM} / \mathrm{s}$ by $\mathrm{E}$. coli Lon (Fig. 8B).

\section{DISCUSSION}

E. coli Lon exhibits varying degrees of energy requirement towards hydrolysis of different protein and peptide substrates. The degradation of protein substrates stimulates ATP hydrolysis while the degradation of small peptides such as GIt-Ala-Ala-Phe-MNA inhibits ATP hydrolysis (19). It is impossible to unambiguously define the reason for the difference in nucleotide requirement in peptide degradation because the $\lambda$
$\mathrm{N}$ protein and GIt-Ala-Ala-Phe-MNA differ by size, amino acid sequence, and the location of $L$ on cleavage sites. One or a combination of these attributes may contribute to the observed difference exhibited by the two Lon substrates. To examine this issue, we synthesized FRETN 89-98 based upon the degradation profile of $\lambda \mathrm{N}$ protein (20) and examined the specificity of Lon-mediated cleavage as well as its effect on ATP hydrolysis by E. coli Lon. This peptide contains a single Lon cleavage site, it is substantially larger than the traditionally used tetrapeptide substrates, and thus it can be used to initially address the effect of peptide length toward ATPase stimulation. Nevertheless, GltAla-Ala-Phe-MNA also differs from FRETN 89-98 by its peptide sequence and the Lon cleavage site sequence (Fig. 1). Therefore we cannot rule out the possibility that the observed difference in ATPase stimulation and peptide degradation between FRETN 89-98 and GIt-Ala-Ala-Phe-MNA degradation is attributed to peptide sequence rather than peptide length. Examination of the changes in Lon activities using truncated FRETN 89-98 peptide substrates will be required to further address this issue.

By incorporating a long-range fluorescence resonance energy transfer pair, $\mathrm{Abz}$ and $\mathrm{Y}\left(\mathrm{NO}_{2}\right)$, into a peptide substrate, the ATP-dependent cleavage of FRETN 89-98 by Lon can be continuously monitored. Since other peptidase assays of Lon are discontinuous (2), the FRETN 89-98 peptide provides a convenient alternative toward characterizing Lon activity. The quenching mechanism of $\mathrm{Abz}$ by $\mathrm{Y}\left(\mathrm{NO}_{2}\right)$ has been demonstrated to involve a long-range resonance energy transfer type in which the quenching efficiency varies linearly with the distance separating the quencher $\mathrm{Y}\left(\mathrm{NO}_{2}\right)$ and the fluorophore (Abz) $(31,35)$. As demonstrated by Meldal and Breddam (31), complete fluorescence quenching is observed over distances of more than $20 \AA$ that separate the donor and the quencher, and only $18 \%$ of the quenching efficiency is lost when the donor and acceptor are separated by $50 \AA$ in a 16-amino-acid peptide. Therefore utilization of peptide substrates containing the $\mathrm{Y}\left(\mathrm{NO}_{2}\right)$ and $\mathrm{Abz}$ functionalities will allow for kinetic characterization of Lon degrading longer synthetic peptides.

Although FRETN 89-98 contains only part of the $\lambda \mathrm{N}$ protein sequence, it is cleaved effectively by $\mathrm{E}$. coli Lon in the presence of ATP (Table 2). LC/ESIMS analysis (Fig. 3) indicates that E. coli Lon specifically cleaves FRETN 89-98 at Cys93 and Ser94, which is also the same cleavage site in the native $\lambda \mathrm{N}$ protein. F urthermore, one unique feature of FRETN 89-98 is its ability to stimulate ATP hydrolysis by $\mathrm{E}$. coli Lon with concomitant degradation. Employing this technique, values of $\mathrm{k}_{\text {cat }},[\mathrm{S}]_{0.5}$, and $\mathrm{k}_{\text {cat }} /[\mathrm{S}]_{0.5}$ were readily determined (Table 2). Our data indicate sigmoidal kinetics in FRETN 89-98 degradation by $\mathrm{E}$. coli Lon using 0.5 
mM ATP. This study reports the first sigmoidal behavior in peptide degradation by Lon. The appearance of sigmoidal kinetics in enzyme velocity curves suggests cooperativity of the substrate binding events that precede the catalytic steps at the active sites. However, it has been noted that a two-substrate enzyme that follows a random-ordered mechanism can display sigmoidal kinetics without true cooperativity $(37,38)$. Therefore FRETN 89-98 will be an important tool to further define the observed sigmoidal kinetic behavior of Lon.

The degradation of FRETN 89-98 by $E$. coli Lon is most effective using ATP as the cosubstrate. In fact, ATP analogs such as AMPPCP and ATP $\gamma$ S which generally support peptide cleavage by $L$ on $(2,19)$ exert no stimulatory effect on FRETN 89-98 degradation. F urthermore, substrates capable of stimulating ATP hydrolysis in general display high specificity constants as peptidase substrates of Lon (Table 2). While the catalytic efficiency $\left(\mathrm{k}_{\mathrm{cat}} /[\mathrm{S}]_{0.5}\right)$ of FRETN 89-98 degradation by $\mathrm{E}$. coli Lon approximates that of protein substrates, it is 1000-fold higher than the tetrapeptide substrate Glt-Ala-Ala-Phe-MNA (Table 2). Since both FRETN 89-98 and protein substrates stimulate while Glt-AlaAla-Phe-MNA inhibits the ATPase activity of E. coli Lon, FRETN 89-98 will serve as a valuable substrate for probing the molecular mechanism of peptide-induced ATPase activity of Lon.

The ability of FRETN 89-98 to serve as a substrate of the truncated human Lon has al so been assessed. Compared to $E$. coli Lon, the human enzyme is 25-fold slower in cleaving FRETN 89-98 under identical reaction condition (Fig. 8B). The reason for the observed difference in the rate of FRETN 89-98 cleavage cannot be deduced from this study. Further kinetic characterization of FRETN 89-98 degradation by human Lon, however, should provide interesting insight into the fundamental substrate discrimination mechanism among I on homologs.

In conclusion, we have demonstrated that ATP hydrolysis contributes to the efficiency of FRETN 89-98 peptide cleavage. The $\mathrm{E}$. coli Lon cleavage profile of FRETN 89-98 is nearly identical to that of the native $\lambda$ $\mathrm{N}$ protein, thereby validating the utilization of FRETN 89-98 as an in vitro substrate mimic to probe the mechanism of ATP-dependent proteolysis. Since human Lon also cleaves FRETN 89-98 in an ATP-dependent fashion, we propose that the FRET peptidase assay will be a very useful tool in kinetic characterization Lon catalysis.

\section{ACKN O WLEDGMENTS}

We thank Dr. P. Garner, S. Dey, and Y. Huang for assistance in peptide synthesis and utilization of instrumentation. We thank Dr. R. Marchant for utilization of spectrophotometer. We thank Kirsten McNamara and Carl Venezia for assistance in preparing recombinant human Lon.

\section{REFERENCES}

1. Gottesman, S., Gottesman, M. E., Shaw, J. E., and Pearson, M. L. (1981) Protein degradation by protease La from Esche richia coli. J . Cell. Biochem. 32.

2. Goldberg, A. L., Moerschell, R. P., Chung, C. H., and Maurizi, M. R. (1994) ATP-dependent protease La (Ion) from Escherichia coli. Methods Enzymol. 244, 350-375.

3. Goldberg, A. L. (1992) The mechanism and functions of ATPdependent proteases in bacterial and animal cells. Eur. J . Biochem. 203, 9-23.

4. Maurizi, M. R. (1992) Proteases and protein degradation in Escherichia coli. Experientia 48, 178-201.

5. Rep, M., van Dijl, J . M., Suda, K., Schatz, G., Grivell, L. A., and Suzuki, C. K. (1996) Promotion of mitochondrial membrane complex assembly by a proteolytically inactive yeast Lon. Science 274, 103-106. [Published erratum appears in Science (1997) Feb 7;275(5301), 741]

6. Suzuki, C. K., Suda, K., Wang, N., and Schatz, G. (1994) Requirement for the yeast gene LON in intramitochondrial proteolysis and maintenance of respiration. Science 264, 891.

7. van Dyck, L., Neupert, W., and Langer, T. (1998) The ATPdependent PIMI protease is required for the expression of intron-containing genes in mitochondria. Genes Dev. 12, 15151524.

8. Teichmann, U., van Dyck, L., Guiard, B., Fischer, H., Glockshuber, R., Neupert, W., and Langer, T. (1996) Substitution of PIM 1 protease in mitochondria by Escherichia coli Lon protease. J . Biol. Chem. 271, 10137-10142.

9. Wang, N., Maurizi, M. R., Emmert-Buck, L., and Gottesman, M. M. (1994) Synthesis, processing, and localization of human Lon protease. J . Biol. Chem. 269, 29308-29313.

10. Wang, N., Gottesman, S., Willingham, M. C., Gottesman, M. M., and Maurizi, M. R. (1993) A human mitochondrial ATP-dependent protease that is highly homologous to bacterial Lon protease. Proc. Natl. Acad. Sci. USA 90, 11247-11251.

11. Robertson, G. T., Kovach, M. E., Allen, C. A., Ficht, T. A., and Roop, R. M., 2nd (2000) The Brucella abortus Lon functions as a generalized stress response protease and is required for wildtype virulence in BALB/C mice. Mol. Microbiol. 35, 577-588.

12. Goldberg, A. L., and Waxman, L. (1985) The role of ATP hydroIysis in the breakdown of proteins and peptides by protease La from Escherichia coli. J . Biol. Chem. 260, 12029-12034.

13. Menon, A. S., and Goldberg, A. L. (1987) Binding of nucleotides to the ATP-dependent protease La from Escherichia coli. J . Biol . Chem. 262, 14921-14928.

14. Menon, A. S., Waxman, L., and Goldberg, A. L. (1987) The energy utilized in protein breakdown by the ATP-dependent protease (La) from Escherichia coli. J . Biol. Chem. 262, 722-726.

15. Menon, A. S., and Goldberg, A. L. (1987) Protein substrates activate the ATP-dependent protease La by promoting nucleotide binding and release of bound ADP. J . Biol. Chem. 262, 14929-14934.

16. Chung, C. H., and Goldberg, A. L. (1982) DNA stimulates ATPdependent proteolysis and protein-dependent ATPase activity of protease La from Escherichia coli. Proc. Natl. Acad. Sci. USA 79, 795- 799.

17. Fischer, H., and Glockshuber, R. (1993) ATP hydrolysis is not stoichiometrically linked with proteolysis in the ATP-dependent protease La from Escherichia coli. J . Biol. Chem. 268, 2250222507.

18. Waxman, L., and Goldberg, A. L. (1982) Protease La from Escherichia coli hydrolyzes ATP and proteins in a linked fashion. Proc. Natl. Acad. Sci. USA 79, 4883- 4887. 
19. Waxman, L., and Goldberg, A. L. (1985) Protease La, the Ion gene product, cleaves specific fluorogenic peptides in an ATPdependent reaction. J . Biol. Chem. 260, 12022-12028.

20. Maurizi, M. R. (1987) Degradation in vitro of bacteriophage lambda N protein by Lon protease from Escherichia coli. J . Biol. Chem. 262, 2696-2703.

21. Van Melderen, L., Thi, M. H. D., Lecchi, P., Gottesman, S., Couturier, M., and Maurizi, M. R. (1996) ATP-dependent degradation of CcdA by Lon protease. Effects of secondary structure and heterologous subunit interactions. J. Biol. Chem. 271, 27730-27738.

22. Legault, P., Li, J ., Mogridge, J., Kay, L. E., and Greenblatt, J . (1998) NMR structure of the bacteriophage lambda N peptide/ boxB RNA complex: Recognition of a GNRA fold by an argininerich motif. Cell 93, 289-299.

23. Van Gilst, M. R., Rees, W. A., Das, A., and von Hippel, P. H. (1997) Complexes of $\mathrm{N}$ antitermination protein of phage with specific and nonspecific RNA target sites on the nascent transcript. Biochemistry 36, 1514-1524.

24. Suzuki, C. K., Rep, M., van Dijl, J . M., Suda, K., Grivell, L. A., and Schatz, G. (1997) ATP-dependent proteases that also chaperone protein biogenesis. Trends Biochem. Sci. 22, 118-123.

25. Garner, P., Dey, S., Huang, Y., and Zhang, X. (1999) Modular nucleic acid surrogates. Solid phase synthesis of alpha-helical nucleic acids. Org. Lett. 1, 403- 405.

26. Sambrook, J ., Fritsch, E. F., and Manitatis, T. (1989) Molecular Cloning: A Laboratory Manual, 2nd ed. Cold Spring Harbor Press, Cold Spring Harbor, NY.

27. Harris, E. L. V., and Anfal, S. (1995) Protein purification methods. In The Practical Approach Series (Hames, D. R. a. B. D. Ed.) pp. 15-16. IRL Press, New York.
28. Fu, G. K., and Markovitz, D. M. (1998) The human LON protease binds to mitochondrial promoters in a single-stranded, site-specific, strand-specific manner. Biochemistry 37, 1905-1909.

29. Berdis, A. J ., and Benkovic, S. J . (1996) Role of adenosine 5'triphosphate hydrolysis in the assembly of the bacteriophage T4 DNA replication holoenzyme complex. Biochemistry 35, 92539265.

30. Wellings, D. A., and Atherton, E. (1997) Standard Fmoc protocols. Methods Enzymol. 289, 44- 66.

31. Meldal, M., and Breddam, K. (1991) Anthranilamide and nitrotyrosine as a donor-acceptor pair in internally quenched fluorescent substrates for endopeptidases: Multicolumn peptide synthesis of enzyme substrates for subtilisin carlsberg and pepsin. Anal. Biochem. 195, 141-147.

32. Zhong, W., and Benkovic, S. J . (1998) Development of an internally quenched fluorescent substrate for Escherichia coli leader peptidase. Anal. Biochem. 255, 66-73.

33. Burdick, D. J ., and Stults, J. T. (1997) Analysis of peptide synthesis products by electrospray ionization mass spectrometry. Methods Enzymol. 289, 478- 498.

34. Woody, R. W. (1995) Circular dichroism. Methods Enzymol. 246, 34-71.

35. Lakowicz, J . R. (1999) Principles of Fluorescence Spectroscopy, Plenum, New York.

36. Piszkiewicz, D. (1977) Metabolic Regulation by Enzymes, Oxford Univ. Press, New York.

37. Copeland, R. A. (1996) Enzymes. A Practical Introduction to Structure, Mechanism and Data Analysis, VCH, New York.

38. Segel, I. H. (1993) Enzyme Kinetics. Wiley, New York. 